\title{
INNOVATION, R\&D AND INDUSTRIAL RESTRUCTURING IN CENTRAL AND EASTERN EUROPEAN COUNTRIES
}

\author{
Igor Yegorov \\ Centre for SET and Science History Studies, National Academy of Sciences of Ukraine, Kyiv, Ukraine
}

\begin{abstract}
The article deals with the problems of development of the R\&D and innovation systems in the Central and Eastern European (CEE) countries. Despite evident positive results in economic transformation, these countries have serious problems in innovation sphere. In turn, lack of in-house R\&D and innovation activities negatively affects the growth rates of national economies. Recent tendencies in innovation development in CEE countries are promising but the gap between them and developed EU countries is still substantial.
\end{abstract}

Key words: Central and Eastern Europe, innovation, industrial restructuring, technology transfer.

\section{INTRODUCTION}

Innovations and R\&D play really crucial role in the processes of economic development in the modern world. At the macrolevel their exact contribution to the economic development is difficult to assess [1] but, anyway, it recognizes widely by the absolute majority of economists [2].

At the microlevel, innovations lead to a number of positive results, including higher productivity, entering the new markets, higher quality of production and etc. Unfortunately, theorists of transition process pay no enough attention to the innovative component of economic transformation, focusing mainly on institutional and organizational aspects of changes in Central and Eastern European (CEE) countries $[3,4]$.

At the same time, it is evident that without proper understanding of the role of innovations and R\&D it would not be possible to evolve a balanced view of the processes of transition and to make a reliable forecast for the further development of the CEE countries.

Unfortunately, in many countries of the region governments, as well as industrial leaders, have no clear understanding of significance of innovations and new technologies in restructuring process, when state policy stimulates development of the technologically advanced sectors with higher than average level of valueadded. In many CEE countries innovation policy and transformation of R\&D system has not been in the focus of local governments. As a result, transformations of these important components of modern economic system was rather 'chaotic' and in some cases not rational in early 1990s. Later, the attitude to the S\&T policy has been changed but loses of the early transition period was difficult to compensate in late 1990searly 2000 s.

○ SCIENCE AND INNOVATION. 2005 


\section{EXPANSION OF NEW SECTORS} AND INNOVATIONS AS MEANS OF ECONOMIC RESTRUCTURING

Economic restructuring involves actions by enterprise to bridge the gap between current performance and what is required in order to become internationally competitive. These gaps emerge as a result of global changes in technology, organization, marketing, and factor prices. Industry, in turn, is prompted by policy, regulatory and institutional changes to improve its competitiveness [5]. Generally speaking, restructuring is successful, when a firm or an industry has shifted to a product mix and cost structure that is competitive and - that is very important - positioned to remain competitive. This could be provided by active innovations and permanent introduction of new products in the international and local markets. At macro level, innovations usually lead to positive changes in the industrial structure, when the shares of modern, technologically sophisticated industries are growing faster that the shares of other industries. This process is accompanied with accelerated growth of companies' profits and diversification of industrial production.

In all industrialized nations the long-term growth of business and, thus, of nations, stems from their ability to develop and produce innovative products permanently. As Freeman argues, "not to innovate is to die" [6, p. 266].

In 1990s - beginning of 2000s, dynamics of industrial development in Central European and post-Soviet countries were controversial and unstable. In late 1980s - 1990s, all countries of the region have passed through a difficult period of recession, but the time of this recession and depth of economic decline were different. Central European economies have adjusted relatively quickly to the new realities, while in the post-Soviet states crisis has continued for a decade and GDP shrunk by several times in the case of Transcaucasian states, some
Central Asian countries, Moldova and Ukraine. In a recovery phase, some countries, like Czech Republic, Hungary, Poland and Estonia had growth rates of industrial development, that was higher than corresponding growth rates of GDP. In some other countries, like Latvia, Slovakia and Lithuania situation was just the opposite. As to the industrial growth itself, there is no universal trend towards slower growth rate in the region. The only conclusion could be made is that slower growth is characteristic of more advanced countries of the region with higher per capita incomes.

The economic slump has led to significant structural changes in the CEE economies. The share of industry, especially the share of manufacturing sectors, dropped significantly, while the share of services grew steadily. In parallel, all transition economies have experienced considerable loses of working places in industrial sector, especially in some high tech industries.

Structural changes in macro level of the national economies were accompanied by the changes within industries themselves. In all transition economies, excluding Hungary and Slovenia, the share of manufacturing declined significantly, while the shares of energy sector and heavy industries had tendencies to grow.

Central European countries and especially countries, which have become new EU members in 2004, have actively transformed their economies to adjust them to the common EU market. Some of them, like Czech Republic, Estonia and Hungary have attracted substantial amounts of FDI. Many companies in these countries have become specialized subcontractors or subsidiaries of leading foreign firms. Western European, American, South Korean and Japanese companies have brought new technologies and helped their Eastern European partners to enter the new markets. Usually, partnership with foreign firms forces Eastern European companies to undertake more active restructuring policy, than they do without it [7]. 


\section{Special Issue}

Table 1. Gross domestic expenditures on R\&D in selected CEE countries (million USD, current prices, recalculated in accordance with Purchasing Parity Powers (PPP) of the national currencies), compiled from OECD Main S\&T Indicators, Vol. 2004/2, Paris, OECD, p. 19 and 57

\begin{tabular}{|l|c|c|c|c|c|c|c|}
\hline Country/year & $\mathbf{1 9 9 1}$ & $\mathbf{1 9 9 8}$ & $\mathbf{1 9 9 9}$ & $\mathbf{2 0 0 0}$ & $\mathbf{2 0 0 1}$ & $\mathbf{2 0 0 2}$ & $\mathbf{2 0 0 3}$ \\
\hline Czech Republic & 2404 & 1635 & 1642 & 1820 & 1832 & 1862 & 1975 \\
\hline Hungary & 1048 & 752 & 790 & 969 & 1192 & 1334 & 1270 \\
\hline Poland & - & 2467 & 2658 & 2602 & 2534 & 2360 & - \\
\hline Slovak Republic & 888 & 437 & 370 & 374 & 381 & 359 & 380 \\
\hline Romania & - & 609 & 498 & 473 & 537 & 542 & - \\
\hline Slovenia & - & 434 & 475 & 498 & 568 & 587 & - \\
\hline
\end{tabular}

The share of internationally competitive goods and services, delivered by these companies has robust tendency to grow.

In mid-1990s Central European countries started transformation of their Soviet-type scientific systems into modern innovation systems, similar to innovation systems of developed countries.

This process was accompanied with substantial changes in $R \& D$ activities, which were reflected in dynamics of key indicators (see table 1).

As it is shown in the table 1, majority of CEE countries could not reach the pre-reform level of 1990s. At the same time, it is evident the dynamics of the recent years is mainly positive. But the R\&D expenses per capita are still 2-15 times lower in the CEE, than in Western Europe. The figures for the number of researchers per thousand of total employment has similar dynamics but here the difference with Western countries is much smaller 1.5-2 times, and some countries, notably - Slovenia, have volumes of this indicator that are even higher than the average figure for the EU. This means that expenses per researcher in CEE are much lower than in the EU.

The share of financing from business sector in Central and Eastern European countries is also lower than $50 \%$, that is less than in the EU (with the exception of Czech Republic), but usually it is higher than in the less developed EU countries of Southern Europe.

In 1990s, a number of concepts of national innovation systems were evolved [8,9] to open the way for complex studies of the industrial and S\&T systems in different countries. These concepts contain so-called "stylized facts", that are common for description of all innovation systems. For instance, in this context the ownership advantage of the firm (technology, brand, marketing, managerial skills) may be treated as specific assets. But the primary economic 'function' of innovations is to gain advantages in competition and, as a result, to higher profits and stronger positions in the markets. But short-term profit growth is not the primary goal for any advanced company. Innovation system is liable to be socially embedded in such a way that that the innovativeness of individual firms will be influenced by socially specific, and extra organizational factors, such as infrastructure of financial institutions, labour markets and provision of workforce training, mechanisms governing the support of business start-ups and development, attitudes and policy concerned with science and technology and the potency of pervasiveness of inter-firm and firm-institutional 


\section{Technologies, innovation management and technology transfer}

interaction [10]. It is widely recognized that technological innovations are playing really crucial role in modern economic development. For a number of economists the level of technological competence of a given country is seen as a basic factor constraining productivity of its industrial sector, with technological advance the central driving force behind economic growth [11]. In this context 'institutions' are considered as moulding the technologies used by a society, and technological change itself. It is even possible to conclude that, to some extent, the influence of country's institutions on its ability to master and advance technology is a central way institutions affect economic performance.

Internationalization of production in modern economy calls for competitive strategies that are coherent in the face of powerfully supported international rivals, and generally requires reliable allies. This also requires creation of equal opportunities for different companies from the side of the state, as well as support of innovative companies are key precondition for successful restructuring and further development.

Economic restructuring is a permanent process, and innovations are playing a crucial role in it. Every company makes its individual decisions about introduction or non-introduction of innovations. On the other hand, within the new conceptions of techno-economic development innovation process could not be understood as the outcome of independent decisionmaking at the level of the firms but rather must be viewed as an interactive, cumulative and cooperative phenomenon, which incorporates more than simple phased multilateral or bilateral interactions between the users, industry and the science base. Successful development of new technologically advanced sectors in Ireland and Finland in recent years gives an important example of how to 'orchestrate' the process of restructuring.

\section{ENHANCING COMPETITIVENESS THROUGH INTRODUCTION OF NEW TECHNOLOGIES}

Introduction of new technologies and growth of competitiveness are interrelated processes. It is difficult to determine these connections quantitatively in terms of reasons and results. At the firm level, final success depends not purely on 'technological' factors but also on organizational framework of the company, situation in the market, sector specificity and so on. In general, higher innovativeness is associated with higher competitiveness. So, in recent years the shares of innovative enterprises in CEE countries were between $6 \%$ and $20 \%$, while in Poland between $30 \%$ and $50 \%$, and in the countries of the European Union average share was around $60 \%-70 \%$. These figures correlate with all major indexes of competitiveness for national economies [12].

But, again, the level of innovativeness could not be itself an indicator of commercial success. A high frequency of innovative activities in the early period of restructuring reflect intensive 'searching' activities of enterprises that tried to enter new markets with new products or technologies. As a part of their diversification efforts, enterprises are launching new products, which later have to be withdrawn from the market in a number of cases due to their marketing, high costs or quality problems. The pure technical novelty is very often insufficient for commercialization. So, innovation is an important precondition, not guarantee for commercial success.

Central European countries are re-integrating into world economy on the base of so-called foreign - led modernization, when technology transfer and innovation processes are strongly shaped by the strategies of multinational corporations (MNC) and WTO-based international trade regimes. Deep involvement of foreign capital and management into processes of restruc- 


\section{Special Issue}

turing determine directions of innovation policy in these countries. A lot of enterprises in the region are included into MNC production chains and use their technological expertise. Hungary, probably gives the most vivid example of such interaction: more that three quarters of Hungarian industry belongs to foreign owners. Average level of productivity in these enterprises is two times higher that in the 'purely' Hungarian firms. Companies, controlled by foreigners, provide more than $80 \%$ of industrial export.

Another important tendency in Central European countries is a growing specialization of their economies. At the same time, economies of the most advanced countries of the region (Hungary, Poland, Czech Republic) have experienced a less dramatic reinforcement of production patterns based on their inter-industry specialisation, and much more on intra-industry specialisation. In the countries of Central Europe, after a decade and a half of institutional transition the relevant issue for the long-term growth and competitiveness is whether or not integration into MNCs structures is pushing these economies towards long-term growth based on innovation and permanent industrial upgrading. This is not an easy question, as chosen model of development reduces scope for autonomous actions and makes these countries extremely dependent on foreign markets, capital, know-how and even organizational capabilities.

The situation is different in the post-Soviet states. They use mainly model of domestic-led modernization, while main assets still belong to national firms. But even such rich in natural resources countries, as Russia could hardly expect any fast restructuring of such sectors as automotive industry or telecom without inflow of foreign capital, innovations and management. Russian situation is specific, as the country has vast natural resources. Russian specialization in natural resources could lead to the typical 'lock- in' situation. As some experimental studies show, in general, growth based on increased specialization in export ultimately needs to be complemented by an increased product variety. Long-term growth rests on complementary relationships between scale and scope. An increased variety of products is subsequently followed by enhancements of specialization in those products proven to be competitive in external and/or internal markets [13].

In conditions of growing role of knowledge in modern economy, companies are modifying their businesses with the aim to increase 'intellectual' components in their businesses. In general, intellectual assets are playing a growing role in production processes, especially in hitech sectors. Mass-production is combined with individual client-oriented approach. Not production itself only but provision of specific services has become a usual practice for a number of companies. Electronic devices have become part and parcel of many traditional goods. In some sectors companies, which produce so-called 'large systems', such as airplanes, companies have to co-ordinate their efforts with thousands of subcontractors. All this requires new technical skills and managerial capabilities for successful development. Modern firms require substantial in-house capacity to recognize, evaluate, negotiate, and finally adapt the technology potentially available from different sources. As authors of the seminal work on 'absorptive capacity' showed, it is increased by doing one's own R\&D, even if much of that appears to be 'imitative' [14]. Failure to conduct research within enterprises not only leads to incorrect choices but restricts the ability to make modifications to the technology that may be essential to market success. Von Tunzelman stresses this very important problem of the CEE countries [15]. Under transition, most of these countries have seen a collapse of $R \& D$ measured at the national level, and particularly a collapse of business expenditure on $\mathrm{R} \& \mathrm{D}$. This implies a 
Table 2. Shares of selected CEE countries in 'triadic' patent families (priority year), \%, compiled from OECD Main S\&T Indicators, Vol. 2004/2, Paris, OECD, p. 51 and 57

\begin{tabular}{|l|c|}
\hline Country \year & $\mathbf{2 0 0 1}$ \\
\hline Czech Republic & 0.03 \\
\hline Hungary & 0.07 \\
\hline Poland & 0.01 \\
\hline Slovak Republic & 0.01 \\
\hline Romania & 0.005 \\
\hline Slovenia & 0.01 \\
\hline
\end{tabular}

national weakening of the ability to imitate and modify technologies. A new dependence on EU and global sources of technology has emerged MNCs are being entrusted to bring in new technology through FDI and management. 'While that is well and good as a way of overcoming short-term deficiencies, it is not a sustainable basis for long-term development. We have thus witnessed a disintegration of alarming proportions of 'national system of innovation' in the CEE countries since 1989' [16, p.19]. The total share of the CEE countries in the world patent is much lower than the share of 'average' EU country (see table 2).

Almost all CEE countries have highly negative technology balance of payments. It is not surprising, but the problem is the figures of technology exchange are much lower than in neighbouring Western European countries. To some extent this could be explained by the fact that MNCs could conduct technology transfer to their subsidiaries through internal channels. This also means that national companies are not very active in innovation sphere. This could be also confirmed by the data from national innovation surveys in CEE countries.

The relative degradation of national innovation systems further reduces the attractive- ness of these countries to its bright and competent prospective young talent. This is clearly a major social problem in the countries that most suffer from it, and one that will have long-term effects on economic growth and techno-economic development.

In the socialist economy, innovation process was hierarchically organized with much stronger linkages on vertical levels that on horizontal ones. Different elements of innovation cycles were located within the different hierarchies. The absolute majority of innovation projects was carried out within the Academy of Sciences, some military-industrial complex institutes and the Universities, while development work was fragmented among other sectors (branch institutes, large enterprises and so on). The actual design of new production lines was carried out by organizations normally subordinate to the industrial ministries, or in some cases to the central planning authorities. Economic development was strictly oriented on expansion, and several types of techno-economic systems co-exited in the Soviet-type industry at the same moment. In practice, this means that due to expansion targets, it was really difficult to stop production to re-equip any more or less important factories. In conditions of a closed, centrally planned economy, only the military sector had to compete with foreign producers, but in most of the cases not on the basis of costefficiency principles. At the end, even military industrial complex has started to suffer from declining standards in the rest of the economy.

A lot of enterprises from the advanced sectors in the Central European and the postSoviet states have stopped their production in the period of crisis. But there are still some reserves for development in high-tech sectors in these countries. In fact, most of previously independent Eastern European firms have become parts of large MNCs (Videoton in Hungary, Scoda - in Czech Republic) or were converted into smaller service companies (Izot - in 


\section{Special Issue}

Bulgaria). Some companies have become effective specialized suppliers to Western firms. These companies are generally small, and provide high performance inputs into complex systems of production and of information processing, in the form of machinery, components, instruments or software. Technological accumulation takes place through the design, building and operational use of these production inputs. To some extent, even large companies from the region could be considered as specialized suppliers. In this case, all participants preserve their independence, but pooling financial and intellectual resources into specific project.

Another group of companies are operating as subcontractors in some projects. In this case, Western partner establishes its own standards for inputs and exerts control over the quality of supplies. In the process of cooperation Eastern partner usually receives access to limited number of technologies and know-how. In many cases, organization of new forms of cooperation between Western and Eastern enterprises has 'asymmetric' nature, as Western partner, as a rule, has more different resources and takes the lead in such alliances.

At the same time, it is also important to mention that research institutes and design bureaus in the CEE countries contain the results of $R \& D$, which represent a potential of billions of dollars in commercial value. But technologies for domestic development and technologies and products ready for competition in the world market are different things. Anyway, there is a potential opportunity for establishing more 'balanced' relations with Western partners in these cases.

Some leading research institutes have already transformed themselves into researchproduction companies, with preservation of some $R \& D$ and creation a dozens of spin-offs that are doing business, including production of goods, on the base of former institutes. Such examples are relatively numerous among tech- nology-oriented institutes in the post-Soviet states. But very often these companies could not overcome relatively high entry barriers that exist in foreign markets, especially in developed countries. Costs related to patenting, marketing and dissemination of their products appear unacceptable in many cases. So, they are moving to the emerging markets of South-East Asian countries, Arab states and some other regions. But such strategy could not be considered as a long-term one. Situation in the lowest segments of the market is usually strain and unstable. To be competitive companies have to try to enter the largest and the most sophisticated markets.

\section{SMES AND INNOVATION}

Some hopes are connected with creation of small and medium-sized private innovative companies as an alternative to awkward giants of the socialist economy. In some countries small enterprises have started to play important role in the process of transformation of national R\&D systems into national innovation systems. They not only absorb a part of workforce from the large restructured enterprises, but some of them - TSMEs (technology-based SMEs) could also contribute significantly to creation of corresponding technological capabilities in the economy [17].

Their potential success is linked to hard-tovalue growth potential derived from scientific knowledge and intellectual property. At the same time, it is evident that in the early stages of their life cycle, they lack tangible assets that may be used as collateral. In addition to this, their products have little or no track record, are largely untested in markets, and very often have high obsolescence rates.

That is why in transition countries TSMEs have a number of problems with obtaining financial resources for their development.

Friends and families are the most important sources of finance for new firms in all transition

SCIENCE AND INNOVATION. N 4, 2005 


\section{Technologies, innovation management and technology transfer}

countries. In Northern America, some countries of Western Europe, notably in England, 'networks of angels investors ' are capable of pooling relatively large sums to finance the TSMEs. These networks include successful entrepreneurs and corporate executives, and thus are able to provide other forms of assistance. Important role in the success of TSMEs could be explained by a number of factors but the key of them could be summarised in the following way:

- strong entrepreneurial culture;

- strong university-based research with links to private sector - S\&T clusters, especially in California and Massachusetts;

- well-developed equity market;

- important role of government both indirect and direct, including provision of tax benefits and so on.

But in Eastern European countries these networks are underdeveloped and still have no serious impact on TSMEs development. The share of venture capital was slightly higher than $0.1 \%$ of GDP in Poland and Czech Republic in late 1990s - early 2000s, and even lower in other Central European states, while in the USA the meaning of this indicators reached $0.63 \%$ and in the UK and Ireland it was at the level of $0.7 \%-0.8 \%$ of GDP.

Transition countries need much more institutions that would have potential to finance TSMEs. These institutions have to accept high level of risks for high potential profits and the same time, they will not require collateral, nor charge interest payments. It would be also important to provide not only short-term, but also long-term and at least medium term loans and to contribute to the management of the firm.

As to the business environment, it is very useful to create conditions, where entrepreneurs will be willing to sell significant equity to outsiders and also willing either to be acquired or to participate in public offerings. Labour market has to be sufficiently flexible, as top quality managers and technologists will be available to staff growing firms.

It seems that at the current stage of development, it would be extremely difficult to obtain financing for TSMEs from private sources in transition countries. As Hall noted [18], there is fairly clear evidence, based on theory, surveys, and empirical estimations, that small and start-up firms in R\&D- intensive industries face a higher cost of capital than their larger competitors and than firms in other industries.

That is why the state has to play more active role in stimulating creation and development of TSMEs in transition countries. In some cases, even such mechanisms as long-gestation projects, involving basic research with the state support could be justified. There is a plethora of different types of incentives that governments have used, including financial and fiscal incentives, direct lending programmes and so on in Western countries. The problem lies in choosing right combination of these incentives, as government involvement easily creates market distortions, cause problems of moral hazard and adverse selection.

In the some Eastern European states these mechanisms for supporting TSMEs are underdeveloped and they are often used in a pervasive way. It is evident that new high-tech companies need better access to financial resources. Removing serious distortions in the financial sector is a prerequisite for the start and successful development of new businesses. In theory, sound new investments can take place only after the restructuring of enterprises, that supply key intermediary products and only after non-performing assets have been dealt with explicitly. Otherwise, banks will bail out unhealthy investments, raising financial costs and pushing aside healthy new prospects. To improve the financial health and the efficiency of banking system, 


\section{Special Issue}

governments must introduce regulatory incentives and restructure the finances of affected intermediaries [19].

Industrial regulations cover an array of regulations that govern commercial operations, of which the most relevant are those that deter competition, including barriers to entry, exit and expansion.

Typically entry barriers protect dominant local enterprises. Policies designed to foster infant industries often ossify into protection for monopolies or oligopolies. Such progressive rigidities can be the by-product of import-substitution strategies, with governments and firms co-operating to make domestic production capacity equal domestic demand. Entry barriers protect incumbent enterprises in domestic markets from challenge of new entrants. As a result, the gap in competitiveness widens between firms operating in the world market and enterprises operating in protected sub-sectors. But in many cases, it is possible to establish some kind of transitional period for particular enterprises under a strict state control to adjust their managerial and production systems to a changed environment. Shock from immediate entry to the market from centrally-planned system have destroyed a number of potentially profitable enterprises.

In any case, it is evident to keep pace with advanced countries, the process of creation of the new technology-oriented companies has to be accelerated in Eastern Europe [20]. At the end, it does not matter whether industrial enterprises absorb R\&D laboratories or research institutions buy factories: the important point is that they have to be integrated. In-house industrial research, most of which is closely linked to the production process, is the cornerstone for successful restructuring of the national economies [21].

\section{DIFFERENCES BETWEEN CEE AND 'OLD' EU COUNTRIES}

The gap between the industrial and research sectors inherited from the socialist period is still substantial, and only development of new technology-oriented businesses could help to reduce it.

As Radosevic stresses, during the 1990s, the main source of technology was via imports of capital goods and foreign direct investment. Endogenously generated R\&D and technology played a marginal role in the industrial upgrading of the CEE countries. The current patterns of industrial upgrading, which are most often led by foreign enterprises, will eventually reach their limits without domestically generated R\&D and new technologies [22].

In the most concentrated form the difference between developed Western European countries and the EU could be shown in the difference in the values of the EU benchmarking indicators, presented in the EU innovation scoreboard.

EU innovation scoreboard (EIS) is a composite indicator that uses dozen and a half indicators to proxy R\&D and innovation activities. In the table 3 these indicators for selected CEE countries in 2002 are presented.

This is not surprising that these countries are behind the technology frontier and that the majority of their technological activities are focused on absorption and importation of new technologies. CEE have relatively high positions if consider "human capital category" and worse in positions in almost all other categories.

Unfortunately, limited data availability of trend values for individual EIS categories do not allow to analyse whether there is the tendency of catching-up or falling behind in all directions. However, it would be wrong to conclude that technology effort has not been taking place in these economies. Relatively high quali- 


\section{Technologies, innovation management and technology transfer}

Table 3. EU benchmarking innovation indicators for selected CEE countries, 2001 (adopted from Towards a European Research Area: Key Figures 2002. Special edition. - European Communities, 2001, Luxembourg, 73p)

\begin{tabular}{|c|c|c|c|c|c|c|c|}
\hline № & Indicator & $\begin{array}{l}\text { Czech } \\
\text { Rep. }\end{array}$ & Estonia & Hungary & Poland & Slovenia & $\begin{array}{c}\text { EU } \\
\text { average }\end{array}$ \\
\hline 1.1 & $\begin{array}{l}\text { The share of S\&E graduates in } 20-29 \\
\text { year old population }\end{array}$ & & & & & & 9.32 \\
\hline 1.2 & $\begin{array}{l}\text { Share of economically active } \\
\text { population with tertiary level } \\
\text { education }\end{array}$ & 11.30 & 40.80 & 15.60 & 14.80 & 15.90 & 23.25 \\
\hline 1.3 & $\begin{array}{l}\text { Share of working population } \\
\text { involved in retraining }\end{array}$ & & & & & & 9.65 \\
\hline 1.4 & $\begin{array}{l}\text { Share of employment in high-tech } \\
\text { manufacturing }\end{array}$ & 10.63 & 5.71 & 8.49 & 7.54 & 10.18 & 6.29 \\
\hline 1.5 & $\begin{array}{l}\text { Share of employment in high-tech } \\
\text { services }\end{array}$ & & & & & & 3.27 \\
\hline 2.1 & Public R\&D funding/GDP & 0.47 & 0.48 & 0.37 & 0.44 & 0.64 & 0.62 \\
\hline 2.2 & Business expenditure on $\mathrm{R} \& \mathrm{D} / \mathrm{GDP}$ & 0.82 & 0.12 & 0.26 & 0.30 & 0.75 & 1.14 \\
\hline 2.3 & EPO high-tech patents/population & & & & & & 19.14 \\
\hline 2.4 & USPTO high-tech patents/population & 0 & 0 & 2.08 & 0 & 1.52 & 11.65 \\
\hline 3.1 & Share of SMEs innovating in-house & & & & 4.1 & 16.9 & 41.01 \\
\hline 3.2 & $\begin{array}{l}\text { Share of SMEs in co-operative } \\
\text { innovation }\end{array}$ & & & & & & 15.42 \\
\hline 3.3 & $\begin{array}{l}\text { Share of innovation expenditure/total } \\
\text { sales }\end{array}$ & & & & 4.1 & 3.9 & 3.41 \\
\hline 4.1 & Share of venture capital/GDP & 0.021 & & 0.016 & 0.045 & & 0.09 \\
\hline 4.2 & Share of new capital/GDP & & & & 0.24 & 0.15 & 1.53 \\
\hline 4.3 & $\begin{array}{l}\text { Share of new-to-market } \\
\text { products/total sales }\end{array}$ & & & & & & 5.40 \\
\hline 4.4 & Home internet access & & & & & & 33.40 \\
\hline 4.5 & Share of ICT markets/GDP & 8.49 & & 6.42 & 4.9 & 4.31 & 5.86 \\
\hline 4.6 & $\begin{array}{l}\text { Changes 1993-97 high-tech/value } \\
\text { added }\end{array}$ & & & & & & 9.50 \\
\hline
\end{tabular}


Table 4. Indication of Knowledge -based Economy in North, South and Central-East EU, unweighted averages, 2003

\begin{tabular}{|l|c|c|c|c|}
\hline \multicolumn{1}{|c|}{ Indicator } & EU-15 & $\begin{array}{c}\text { Northern EU (Denmark, } \\
\text { Finland, Sweden) }\end{array}$ & $\begin{array}{c}\text { Southern EU (Spain, } \\
\text { Greece, Portugal, } \\
\text { Italy) }\end{array}$ & CEE EU \\
\hline $\begin{array}{l}\text { GPD per head, } \\
\text { index }\end{array}$ & 100 & 108 & 80 & 44 \\
\hline Innovation level & 0.44 & 0.63 & 0.19 & 0.22 \\
\hline Innovation trend & 9.5 & 11.4 & 16.8 & 26.8 \\
\hline
\end{tabular}

ty of human capital is the key precondition for convergence between the CEE and the rest of the EU.

Using the data from the latest EIS surveys, Wintjes and Dunnewijk [23] showed, that the distance between the new members and two candidate countries (Bulgaria and Romania), on the one hand, and the old EU members, on other, is declining (see table 4).

Innovation trend show how innovation index changes over the time. In recent years the growth rate of innovation activities in CEE was almost three times higher than the average for EU-15 but these countries still perform two times worse than old EU members. The difference between the EU leaders in innovation policy and CEE is even greater.

In 2004, EU Commission recommended its new member states to make substantial efforts aimed at intensification of $R \& D$ and innovations. Key reasons for such recommendation were: low investment in $\mathrm{R} \& \mathrm{D}$ and innovation and retraining activities, low efficiency of education system and vocational training, and in the case of Slovenia and Czech Republic low efficiency of R\&D and innovation. Recommendations to increase investments in business $\mathrm{R} \& \mathrm{D}$ and in vocational training stand as prominent mechanism to increase productivity for all new member states [24].

\section{CONCLUSION}

Central and Eastern European countries have made great steps on their integration into European structures but their attempts to reach higher level of economic development are seriously affected by the lack of attention to the problem of innovation and the effective utilization of the results of national $\mathrm{R} \& \mathrm{D}$ system.

Experience of different countries demonstrate that economic restructuring can be effective only as complements to policies that promote efficient responses by most firms at the economy or at least at targeted industries. Technology transfer and innovations have to play growing roles in successful restructuring, as the modern technologies and know-how provide higher value-added and substantial advantages in front of the competitors.

Bearing in mind rapid changes in technology and markets and the increasing focus on exports, banks, private venture funds and state organizations have to develop specific expertise in project evaluation. Existing technologies and know-how could be commercialized, and bring substantial dividends to the countries in transition. At the same time, technology transfer from the West could help to solve not purely economic, but in some cases, also environmental and social problems, from which countries of the region are still suffering.

SCIENCE AND INNOVATION. N 4, 2005 


\section{Technologies, innovation management and technology transfer}

A common feature of the CEE countries is relatively weak and disorganized constituency in favour of innovation policy and innovation activities. Despite positive dynamics in recent years, these countries need serious reinforcement of their efforts, aimed at the gaining the level of developed Western states.

\section{REFERENCES}

1. Griliches Z. R\&D and Productivity. - University of Chicago Press, Chicago, USA, 1998, 312 p.

2. Silverberg G., Soete L., eds. The Economics of Growth and Technical Change. - Edward Elgar, Aldershot and Brookfield, 1994, 327 p.

3. Aslund A. Building Capitalism. - Cambridge University Press, Cambridge, Mass., USA, 2003, 632 p.

4. Kornai J. The Affinity between Ownership Forms and Coordination Mechanisms: The Common Experience of Reform in Socialist Countries. Journal of Economic Perspectives, vol. 4, N. 3, Summer 1990, pp. 131-147.

5. Lieberman I. Industrial restructuring: World Bank policy and country experience. - WB/IMF Working Paper No 135-92, 1992, 29 p.

6. Freeman Ch., Soete L. The Economics of Industrial Innovation. - Pinter Publishers, 1997, 274 p.

7. Kampos N., Kinoshita Y. Foreign Direct Investment as Technology Transferred: Some Panel Evidence from the Transition Economies. - CEPR Working Paper DP3417, London, UK, 2002, 23 p.

8. Lundvall B.-A., ed. National Systems of Innovations: Towards the Theory of Innovation and Interactive Learning. - London, UK, Pinter Publishers, 1992.

9. Nelson R., ed. National Systems of Innovations. A Comparative Analysis. - Oxford University Press, Oxford, UK, 1993.

10. Dosi J., Teece D., eds. Technology, Organization and Competitiveness: Perspectives on Industrial and Corporate Change. - Oxford University Press, Oxford, UK, 1997.

11. Nelson R., Nelson K. Technology, institutions, and innovation systems. - Research Policy, vol. 31, 2002, pp. 265-272 .

12. Hottop U., Radosevic S., Bishop K. Trade and Industrial Upgrading in Countries of Central and Eastern Europe: Patterns of Scale and Scope-based Learning. - SSEUS Working Paper N.23, University College London, 2003, 28 p.

13. Dyker D. Catching up and Falling Behind: Post-
Communist Transformation in Historical Perspective. - Imperial College Press, UK, 2004, 379 p.

14. Cohen W., Levinthal D. Absorptive capacity: a new perspective on learning and innovation. Administrative Science Quarterly, vol. 35, 1990, pp. 128-152.

15. von Tunzelman N., Wang Q. An evolutionary view of dynamic capabilities. -Economie Appliquee, vol. 16, 2003, pp. 33-64.

16. von Tunzelman N. Changes in the European system of innovation and the EU enlargement process. - in Jasinski A., ed. Transition Economies in the European Research and Innovation Area: New Challenges for their Science and Technology. - Widawnictvo Naukowe Uniwersitetu Warszawskiego, Warsaw, Poland, 2004, pp. 11-25.

17. Freel M. Sectoral patterns of small firm innovation, networking and proximity. - Research Policy, vol. 32, 2003, pp. 751-770.

18. Hall B. The Financing R\&D, NBER Working Paper, N.8773, February 2002, 17 p.

19. Havrylyshyn O., van Rooden R. Institution Matter in Transition, but So Do Policies. - Comparative Economic Studies, vol. 55, N. 1, Spring 2003, pp. $2-24$.

20. Kutlaca D., Radosevic S. Industries, Costs and Macroeconomic Regimes in Central and Eastern European Countries: Towards Stylised Facts. Macrotec Project Research Paper, School of Slavonic and East European Studies, University College London, UK, 2002, 39 p.

21. Laursen K., Salter A. The Fruits of Intellectual Production: Economic and scientific specialisation among OECD countries. - SPRU Electronic Working Paper No 78, The University of Sussex, UK, January, 2002, 17 p.

22. Radosevic S. A two-tier or multi-tier Europe: assessing the innovation capacities of eastern and central European countries on the enlarged EU. - Journal of Common Market Studies, vol. 42, N.3, 2004, pp. 641-666.

23. Wintjes R., Dunnewijk T. Learning how to improve innovation policy in Central and East EU countries. - in Jasinski A., ed. Transition Economies in the European Research and Innovation Area: New Challenges for their Science and Technology. Widawnictvo Naukowe Uniwersitetu Warszawskiego, Warsaw, Poland, 2004, pp. 115-128.

24. Commission Recommendations on the 2004 update of the Broad Guidelines of the Economic Policies of the Member States and the Community for the 20032005 ( Presented in accordance with Article 99 (2) of the EC Treaty) - Brussels, 7.4.2004, COMP (2004)238. 